\title{
Design and Redesign of a Multimodal Classroom Task - Implications for Teaching and Learning
}

\author{
Anne Öman \\ Department of Applied IT, \\ University of Gothenburg, \\ Sweden
}

Anne.Oman@gu.se

\author{
Sylvana Sofkova Hashemi \\ Department of Social and \\ Behavioural Studies, \\ University West, Sweden
}

\section{Sylvana.Sofkova-Hashemi@hv.se}

\begin{abstract}
Digital technologies are increasingly implemented in Swedish schools, which impact on education in the contemporary classroom. Screen-based practice opens up for new forms and multiplicity of representations, taking into account that language in a globalized society is more than reading and writing skills.

This paper presents a case study of technology-mediated instruction at the primary-school level including an analysis of the designed task and how the teacher orchestrated the digital resources during three introductory classes. The aim was also to explore the pupils' redesigning of advertising films based on teacher's instructions and available digital resources. Sequences of a learning trajectory were video recorded and analysed from a multimodal perspective with a focus on the designed task and the processes of how pupils orchestrate meaning through their selection and configuration of available designs.

The findings show a distinction between the selection of design elements in the teacher's orchestration of the laptop resources during instruction and the pupils' redesigning of the task. Pupils' work developed from the linguistic design provided by the teacher towards visual design and the use of images as the central mode of expression in the process of creating advertising films. The findings also indicate a lack of orientation towards subject content due to the teacher's primary focus on introducing the software.
\end{abstract}

Keywords: Multimodality, digital resources, available designs, primary education, collaboration

\section{Introduction}

Learning how to write and read has been traditionally formalized through print-based teaching in

Material published as part of this publication, either on-line or in print, is copyrighted by the Informing Science Institute. Permission to make digital or paper copy of part or all of these works for personal or classroom use is granted without fee provided that the copies are not made or distributed for profit or commercial advantage AND that copies 1) bear this notice in full and 2) give the full citation on the first page. It is permissible to abstract these works so long as credit is given. To copy in all other cases or to republish or to post on a server or to redistribute to lists requires specific permission and payment of a fee. Contact Publisher@InformingScience.org to request redistribution permission. schools (Merchant, 2007; New London Group, 2000). Current patterns of communication embedded in the way we socialize with digital media have impacted the ways in which we learn to read and write. Screen-based activities, including software applications, websites, and wikis, offer new ways to make meaning, challenging the authority of traditional print-based learning (Merchant, 2007). People of all cultures have 
always used a range of ways to represent ideas and communicate meaning but what is different today is the way that messages are relayed and distributed through different media of communication. The digital devices implemented in schools today include a range of modes for expression and communication, and teaching is not limited to traditional means of paper. Everyday communication is made up of combinations of modes on the screen (Bearne \& Wolstencroft, 2007). 'Digital Competence' is also one of the European Union's (EU) eight key competences for lifelong learning (Immerfall \& Therborn, 2010). The Swedish government has a national strategic agenda, which aims to make Sweden a world leader in the use of information and communication technologies (ICT) with regard to both democracy issues and education (Government Offices of Sweden, 2011).

In Western societies, the culture of books and writing has a long tradition. Digital technology representation has moved the writing tradition to the screen and the visual mode (Kress, 2005). The digital world has influenced how we think and act and created a new "landscape of communication" (Kress, 2005, p.183). Many pupils in schools today are surrounded by literacy practices related to digital devices, the Internet, and mobile phones (Miller \& McVee, 2012).

\section{Multimodal Communication in the School Context}

Traditional print-based teaching and learning has dominated the Swedish curriculum. Even though there have been variations in formulations between different curricula and syllabi, printbased activities still dominate compared to other modes (visual, auditory, etc.) (Swedish National Agency for Education, 2013). The current Swedish curriculum emphasizes in many places learning goals based on written and spoken language (Swedish National Agency for Education, 2011). However, there are explicit aims that point out the importance of using and integrating other modes such as image and sound. For instance, the pupils should be given opportunities to work with "texts that combine different modes, e.g., film, interactive games and web pages" (Swedish National Agency for Education, 2011, p. 224).

The number of computers has increased in Swedish schools and digital devices are implemented more and more in daily practice in primary schools. Teachers and pupils have access to ICT, and new forms of representation and communication have to be taken into account in teaching and learning. Written or spoken language is no longer the only way of communication, and there is thus a need to understand the complex ways in which speech and writing interact with other modes (Jewitt, 2011). Developing a classroom environment that includes multimodal resources requires a review of the existing provision of texts for multimodal teaching (Bearne \& Wolstencroft, 2007).

Previous research studies have focused on examining the role of contemporary technologies in classrooms with regard to various issues, e.g., how teachers design tasks and how pupils interact with the digital tools and the affordances of multimodal resources (Bebell \& O'Dwyer, 2010; Edwards-Groves, 2011; Jewitt, 2006, 2008, 2011; Kress, 2010; Mavers, Somekh, \& Restorick, 2002; Selander \& Åkerfeldt, 2008.). Research has provided examples of teacher-designed tasks and software programs that offer new opportunities for learning, such as improved learning by classroom interaction with digital tools, learning and understanding of the subject content through visual modes, and learning by the variation of different modes (Bearne, 2009; Birmingham, Davies, \& Greiffenhagen, 2002; Dils, 1999; Jewitt, 2006; 2008; Mavers, 2003; Tomlinson, 2013; Watters, Conley, \& Alexander, 1998).

Research findings have also shown that pupils engage in multimodal redesign by the orchestration of semiotic modes of music and verbal linguistics in a situated learning context. Children communicate their experiences through multimodal redesign, which enhances their conceptual understanding (Tomlinson, 2013). Other studies point out that pupils also engage in digital and 
multimodal activities outside of the task the teacher has assigned. They try out and integrate various modes of meaning using other digital resources, e.g., the special effects of photo programs (Björkvall \& Engblom, 2010), which allow exploration of designs other than teacher-designed tasks.

Various studies have highlighted the importance of teacher instruction and of guiding pupils in the use of digital tools in order to create potential for learning (Hennessy, Deaney, \& Winterbottom, 2007; Kennewell et al., 2007; Warwick, Mercer, Kershner, \& Kleine Staarman, 2010). In the digital environment teachers, pupils and tools become important in the creation of multimodal learning spaces (Warwick et al., 2010). But there are still barriers to the inclusion of pupils' multimodal texts in formal assessment because of the lack of explicit goals addressing multimodal reading and composition. Several studies express a need for a common discourse about multimodal texts in instruction (e.g., Bearne, 2009; Edward-Groves, 2011).

If teaching has changed to encompass a multiplicity of modes besides the written and spoken language, then this indicates an interest in the ways that pupils integrate these available designs provided by the teacher and the digital resources. In order to make an argument for using multimodal design in teaching, research from different multimodal activities will be needed to shed light on teachers' and pupils' interaction with digital tools and how they orchestrate and apply the affordances of different modes. Voices of teachers and pupils have to be heard and studies of changing classroom practices must be conducted (Miller \& McVee, 2012).

With regard to the concepts of the curriculum and the assessment of pupils' schoolwork, there is a need to understand how pupils mediate the relationship between the teacher's instructions, the digital resources, and the learning goals. There are still too few examples of teachers engaged in new multimodal literacies practices (Miller \& McVee, 2012). From our point of view, in order to achieve an understanding of teacher-designed technology-mediated instruction and its impact on pupils' meaning-making practices, a focus on the trajectories of learning sequences is needed.

\section{The Aim of the Study}

In light of the tradition of print-based teaching in Swedish schools and the emphasis on written and spoken language in the Swedish curriculum, the present case study aims to explore how a teacher introduces a technology-mediated task in comparison to how the pupils redesign the multimodal task. Our hypothesis is that the school traditions have an impact on the ways the teacher orchestrates digital resources in the classroom. However, the sampling of the participants in this case study includes teachers who have previous experience of digital resources in daily teaching, which might be expected to impact on the orchestration of the resources, i.e., the design and introduction of the task. The research questions in the present paper concern various modes of expression and how they are orchestrated during a technology-mediated learning task.

Through a sequence of three introductory mini-lessons, the teacher introduced pupils to the task of making digital advertising films about planets in our solar system on which the pupils then collaborated in groups during a four-week period. In this situated context the pupils were provided with a variety of options for engaging in multimodal productions integrating images, sound, music, text, and speech.

Based on the multiliteracies framework and multimodal analysis as proposed by the New London Group (2000), the design concept has been used as an analytical instrument to clarify the composing processes in pupils' group work. Assuming a sociocultural perspective on pupils' learning and composing practices, as well as adopting the premise that meaning is always mediated, the research questions aim to investigate the teacher's orchestrating of digital resources in contrast to the pupils' selection and integration of modes of meaning based on the available designs provided 
in the teacher's instructions and the digital resources. The research questions observed in the present paper are:

(i) How was the multimodal task designed and introduced during a trajectory of teaching sequences?

(ii) How did the pupils redesign the task using the available designs provided by the teacher and the digital resources?

The remainder of the paper is structured into sections: first, there is a detailed description of the research background, including the methodology, followed by the findings from the analyzed data, and finally a discussion and the conclusions of the study.

\section{Research Background}

\section{Theoretical Foundation}

The New London Group (2000) discusses the concept of Design in the context of what pupils need to learn about literacy as an organizational structure and literacy in the process of meaning making. This concept of Design includes teachers as designing learning processes and environments in order to achieve learning. Designs of meaning include available designs, which are resources for meaning in relation to the discourse in a given social space. Available designs are defined as resources for Design and include various semiotic systems such as language, film, photography, and gestures (New London Group, 2000).

From this perspective, the process of meaning making is never simply a repetition of available designs but "involves the transformation of the available resources of meaning" (New London Group, 2000, p. 22). People develop new uses of old materials in relation to each other and create patterns of meaning in various contexts, resulting in the Redesigned. The outcome of designing is new meanings, which meaning-makers remake themselves (New London Group, 2000, p. 22).

The unit of analysis in this paper is pupils' meaning making in groups in relation to a teacherdesigned task and the digital resources. The analysis is based on a multimodal theory and the framework developed by the New London Group (2000). This theoretical framework has focused on the ways in which modes are combined and designed to make meaning (Jewitt, 2006, 2008). The relevant terms are defined in Table 1.

Table 1: The concept of Design (New London Group, 2000)

\begin{tabular}{|l|l|}
\hline Designs of meaning & $\begin{array}{l}\text { Resources for Meaning; Available designs of } \\
\text { Meaning }\end{array}$ \\
\hline Available Designs & $\begin{array}{l}\text { The work performed on or with Available De- } \\
\text { signs in the semiotic process }\end{array}$ \\
\hline Designing & $\begin{array}{l}\text { The resources that are produced and trans- } \\
\text { formed through Designing }\end{array}$ \\
\hline The Redesigned & \\
\hline
\end{tabular}

The concept of Design (New London Group, 2000) forms the basis for analyzing the classroom communication as digital resources open up for multimodal composing and communication of different modes of expression (linguistic, visual, auditory, gestural, spatial). The teacher designs multimodal learning tasks, and pupils as meaning-makers select and integrate these various 
modes of meaning in relation to the available resources and affordances of different modes and digital resources.

According to the New London Group (2000), teachers and pupils also need meta-language to describe these forms of meaning-making interactions, which support a critical analysis of language and other semiotic systems but do not make unrealistic demands on teacher and learner knowledge. The meta-language should be a tool to identify and explain patterns of meaning in different design areas. In order to do this, the New London Group presented a 'multimodal wheel' and the conception of 'multiliteracies' with six major semiotic activities: linguistic, audio, visual, spatial, gestural, and multimodal design. The latter is more complex because "it represents the patterns of interconnections among the other modes" (New London Group, 2000, p. 25). These different modes of meaning contain certain design elements; for example, in linguistic design there are vocabulary and metaphor, in visual design there are colors and perspective, and in audio design, music, and sound effects.

The term affordances is used here in the sense of which representations of different modes are available in the environment and the potentials and limitations that they afford depending on contextual use. From a sociocultural perspective the orchestration of representational resources can be seen as the interaction between people and objects in a particular context (Vygotsky, 1978). Informed by this sociocultural view, the term affordances is used in this study to mean the way of thinking about what it is possible to express and represent by modes and digital resources (Jewitt, 2006). Digital devices afford both possibilities and limitations for the users.

\section{Multimodal theory}

A multimodal approach, according to Jewitt (2008), moves beyond seeing multimodal resources as decorations. This theory has focused on the ways in which modes are combined and designed to make meaning (Jewitt, 2006, 2008). The basic assumption is that meaning is made through many representational and communicational resources, of which language is one (Kress \& van Leeuwen, 2001). Different modes, such as image, sound, text, speech, and gestures, are viewed as organized sets of semiotic resources for meaning making (Jewitt, 2008; Kress, 2010). This means that each mode in a multimodal ensemble is understood as realizing different communicative activities (Jewitt, 2011). The choice of mode is thus a central aspect of the epistemological shaping of knowledge. Voice, gesture, sounds, and other modes are all resources for meaning making. The orchestration of meaning involves selection and configuration of modes.

Multimodality focuses on all the different resources that are displayed on the computer screen and are part of classroom interaction. Meanings are made in a variety of modes and always with more than one mode (Kress, 2010). All meaning making is multimodal, i.e., gestures accompany sight and language, spoken language is achieved with audio and gestures, and written language is combined with visuals. According to Cope \& Kalantzis (2000), "Multimodal meaning is no more than the other modes of meaning working together, and much more as well" (p.211), which means that multimodal meaning is more than the sum of all modes of meaning.

\section{Research Methodology}

\section{The setting, the participants and the task}

The setting for this case study was a third-grade classroom, located in an urban primary school, that employs digital technologies for pupils' use. The public school is situated in a middle-class area in the south of Sweden where the school children come from different cultural and socioeconomic backgrounds. The primary school is part of a 2-1 laptop-project, providing one computer for every two students. The participants involved in the case study were selected to suit the pur- 
pose of the study ('purposive sampling' (Bryman, 2012)). This particular school was selected because the teachers were working with digital artefacts in daily teaching. The aim of the study was to explore in what ways the digital resources were used for teaching and learning, and the participants have been selected for their relevance to the research questions.

The study as a whole focused on the work of nine-year-old children, grade three, and the school project, 'Space'. The aim of the project was that the pupils should learn about the planets in our solar system by using various forms of digital technology in the learning processes. Over the course of ten weeks, different classroom assignments, both individual and group work, were implemented. The class being studied consisted of 29 pupils, 13 boys and 16 girls, and there were three teachers in total involved in the project work of this class. The head teacher did most of the work during this study while the other two teachers had fewer classes. The empirical material presented in this paper was collected from group work where the aim was to create advertising films about the planets using the film-software, iMovie. A characteristic of this kind of software is that it affords various modes such as image, sound, text, speech, music, and special effects, e.g., colors, backgrounds, etc. The company behind iMovie and the ideas behind the development of this software are not being addressed here. The aim here is not to evaluate the software: the focus of the analysis is on the small-group interactions with the meaning-making modes provided by the digital resources.

The main teacher had designed a task, and, according to the teacher interview, the aim of this task was to "make presentations on the planets in the solar system." This was linked to the Swedish syllabus and the aim of working with texts that combine different modes, e.g., film, interactive games, and web pages (Swedish National Agency for Education, 2011, p. 224). The children were divided into six groups of three to four children where each group was responsible for one planet. None of the pupils had worked with the iMovie software prior to this project. During this task the pupils were given one computer per group.

\section{Data collection method}

The data was collected from a micro-ethnographic perspective by the use of video recordings (Baker, Green, \& Skukauskaite, 2008). To enrich the data, formal and informal interviews were also conducted with both pupils and teachers. Undertaking fieldwork at the same time as video recording provides an opportunity to talk to the participants and discuss what might have arisen or aspects of the material environment (Heath, Hindmarsh, \& Luff, 2010), which was a good complement to the video recordings. The informal interviews with the pupils were carried out during their work at times when it was appropriate to ask questions. The formal semi-structured interviews with the pupils were carried out through group interviews and the initial questions for each group were:

What did you think about the task? What was particularly good, bad, easy, difficult? What did you think about working with the film software?

Each group answered these questions but they also talked about other issues that they had reflected on during the work. The formal semi-structured interviews with the three teachers working in the class were carried out individually. The initiating questions for the teachers were:

Overall reflections on the project, 'Space'? The aim of the project 'Space'? In what ways have the digital resources been used by the students? What was extremely good/bad in this project? Explain! What would you like to develop if doing this kind of project again? Why?

These different data collections were utilized in order to describe and analyze the teaching and learning processes in the classroom, e.g., teachers' introductory lessons and how pupils made meaning during this specific task of creating advertising films. Video recordings were used in order to have the opportunity to analyze tape segments several times (Heath et al., 2010). 
Altogether the data corpus totaled 28 hours of video material. During the data collection, two video cameras were used, one stationary camera that was placed so as to capture the whole-class activity and one mobile camera to zoom in on group activities during the classroom work, which was necessary in order to capture the screen activity. The decision to 'zoom in' (Mifsud, 2012) on certain group activities with one of the cameras meant that not all the sequences of the group activities were closely recorded, because the whole-class view did not capture the screen activities. Nevertheless, a rich corpus of video data was collected because not all of the groups were working with this particular task at the same time.

The field-notes together with the formal and informal interviews and the video recordings made different complementary parts of the data collection and contributed to the findings obtained from the material. Field-notes of the observations were made during and after every lesson and later transformed into digital text.

After finishing the data collection, the first step of the analysis was to carry out a preliminary review of the data corpus. Video recordings, observations and interviews were digitally organized and summarized, divided into different parts and then put together to get an overview (Heath et al, 2010).

The second step was a review of the data in order to find significant features in relation to the research questions and the tools for analyses. In order to analyze the introductory lessons followed by the pupils' group work, the analysis has been developed from the New London Group's (2000) multiliteracies framework, which focuses on design of modes of expression, including available designs, designs, and redesign.

After repeated searches of the data corpus it was possible to identify meaning-making processes that reflected similar characteristics. From these codes, selected parts of the video recordings were later transcribed, producing descriptions of the various modes of meaning in accordance with the designs of the multimodal wheel: linguistic, visual, audio, gestural, and spatial. The transcripts provide a description of the analyzed data and parts of these transcriptions have been used to exemplify the findings from this study.

The data presented in this paper is based mainly on video recordings, but in order to analyze the data it has also been necessary to use other sources of data, particularly the field-notes and interviews made over a period of three months. By 'only' analyzing the video recordings this wider context would have been missed.

To increase the credibility of the research, the goal has been to make the data records systematic as well as making a systematic analysis by comparing different data, video recordings with observations and interviews. The aim was to ensure a consistency between developed concepts and observations.

\section{Findings}

\section{Introducing Multimodal Composing}

According to the interview with the head teacher, the aim of this designed task was to make an advertising film about a planet in the solar system and to use "new digital software in teaching", which she thought could open up for various modes for learning. The learning goals for this task were primarily for the pupils to work with texts that combine different modes, in this case image and text, which can be found in the syllabus for Swedish (Swedish National Agency for Education, 2011). 
The teacher designed this particular task and introduced it to the pupils during three mini-lessons, each approximately 15 minutes long, before the pupils started their projects, which they worked on for four weeks. The main content of the three lessons were introduction of the software and also composition of what the teacher called a manuscript. These lessons mainly focused on introducing the software and not the content of the advertising films, e.g., how to advertise a product. A brief discussion about the content of an advertising film arose when a pupil asked a question about the use of facts or fantasy, to which the teacher responded by explaining that they could use these two genres in combination with each other. The pupils therefore had the opportunity to interpret and design the advertising films from their own experiences of these genres. During the first three mini-lessons there were various artefacts, content and design modes in use, which are summarized in Table 2 . The primary mode in use is marked in bold.

Table 2: Teacher's introductory mini-lessons.

In this table the modes primarily used during the introductory classes are marked in bold.

\begin{tabular}{llll}
\hline Lesson & Artefacts & Content & Design modes \\
\hline $\mathbf{1}$ & $\begin{array}{l}\text { Whiteboard, } \\
\text { paper, pen }\end{array}$ & $\begin{array}{l}\text { Software } \\
\text { Manuscript }\end{array}$ & $\begin{array}{l}\text { Linguistic } \\
\text { Visual, } \\
\text { Gestural, Spatial }\end{array}$ \\
& Projector, laptop & $\begin{array}{l}\text { Software } \\
\text { Manuscript }\end{array}$ & $\begin{array}{l}\text { Linguistic } \\
\text { Visual, } \\
\text { Gestural, Spatial }\end{array}$ \\
& & Internet & Linguistic \\
$\mathbf{3}$ & Projector, laptop & $\begin{array}{l}\text { Repetition of } \\
\text { software and } \\
\text { manuscript }\end{array}$ & $\begin{array}{l}\text { Visual, } \\
\text { Gestural, } \\
\end{array}$ \\
& & & Spatial \\
\hline
\end{tabular}

\section{Introducing the software}

The focus of the first lesson was to introduce the film-software and to show features of the software icons, which illustrate different modes such as text, image and sound boxes. In Excerpt 1 the teacher started out by asking the name of the photo library in iMovie. In this event the whiteboard was used as an artefact.

In Excerpt 1 the teacher introduced the photo library and talked about how to drag and drop photos (Turn 4) and add text (Turn 6). This was done primarily through the linguistic mode but also with visual, gestural and spatial designs:

- Linguistic design: using elements like the voice and words to introduce the task

- Visual design: using the whiteboard as an artefact for illustrations

- Gestural and spatial design: pointing at and illustrating on the whiteboard

The teacher drew boxes in order to illustrate how the advertising film could be built up and the pupils received instructions on how to use the software. In this task the pupils were instructed to use photos or images from the Internet that had previously been saved in the computer library, as well new images, as a base for the creation of the film. New photos could be saved in iPhoto or on the desktop (Turn 4). 
Excerpt 1

\begin{tabular}{|c|c|c|c|c|}
\hline Turn & Actor & Video image & Action/gesture & Speech \\
\hline 1 & Teacher & & $\begin{array}{l}\text { Makes an I in the } \\
\text { air }\end{array}$ & $\begin{array}{l}\text { What is the name } \\
\text { of the library } \\
\text { where all your } \\
\text { photos are saved? } \\
\text { What is the name? }\end{array}$ \\
\hline 2 & Bea & & Raises her hand & iPhoto \\
\hline 3 & Teacher & & $\begin{array}{l}\text { Draws boxes on the } \\
\text { whiteboard }\end{array}$ & $\begin{array}{l}\text { Yes, iPho- } \\
\text { to...that's where } \\
\text { all your photos } \\
\text { are } \\
\text { You right click } \\
\text { and add to iPho- } \\
\text { to library }\end{array}$ \\
\hline 4 & Teacher & & Points at the boxes & $\begin{array}{l}\text {....they have to } \\
\text { be put in the } \\
\text { library or you } \\
\text { can put them } \\
\text { directly on the } \\
\text { desktop... so you } \\
\text { can drag and } \\
\text { drop them into } \\
\text { the film after- } \\
\text { wards... } \\
\text { Then you put the } \\
\text { photos togeth- } \\
\text { er... } \\
\text { And then you can } \\
\text { create the film }\end{array}$ \\
\hline 5 & Teacher & & Watching the class & $\begin{array}{l}\text { Could you add } \\
\text { something more } \\
\text { into the advertis- } \\
\text { ing film? }\end{array}$ \\
\hline 6 & Sven & & $\begin{array}{l}\text { Waves his hand a } \\
\text { little bit }\end{array}$ & $\begin{array}{l}\text { You could add } \\
\text { some text }\end{array}$ \\
\hline 7 & Teacher & & $\begin{array}{l}\text { Draws a box with a } \\
\text { 'T' on the white- } \\
\text { board }\end{array}$ & $\begin{array}{l}\text { Yes there is a } \\
\text { small box here } \\
\text { with a 'T' }\end{array}$ \\
\hline
\end{tabular}

In the next lesson the teacher used the laptop and projector when demonstrating the software and was thus involved mainly in visual design. The teacher continued by talking about different modes of expression represented in the software by pointing out the different icons visually, spa- 
tially and gesturally, and representing them. In excerpt 2 the teacher started out by talking about 'special effects' but left the subject and went on to focus on other modes such as music, photos and text.

In Excerpt 2 the teacher showed the icons of different modes: text, music, and photos. The photos or images could be handled in two ways: students could use the computer library, with a fixed selection of photos, or they could search for images that can be downloaded for free on various websites. The different options were introduced verbally and the web addresses were written on the white board.

\section{Excerpt 2}

\begin{tabular}{|c|c|c|c|c|}
\hline Turn & Actor & Video image & Action/gesture & Speech \\
\hline 1 & Teacher & & $\begin{array}{l}\text { Watches the soft- } \\
\text { ware displayed } \\
\text { on the projector } \\
\text { screen }\end{array}$ & $\begin{array}{l}\text { I will show you some- } \\
\text { thing else as well... } \\
\text { How many special ef- } \\
\text { fects you want to use } \\
\text { depends on how much } \\
\text { you have been working } \\
\text { in this program and if } \\
\text { you would like... } \\
\text { We can do it later... we'll } \\
\text { do it later }\end{array}$ \\
\hline 2 & Teacher & & $\begin{array}{l}\text { Points at the box } \\
\text { with a } \\
\text { musical note }\end{array}$ & $\begin{array}{l}\text { Anyway what is this? } \\
\text { Isabella }\end{array}$ \\
\hline 3 & Isabella & & Has her hand raised & music \\
\hline 4 & Teacher & & $\begin{array}{l}\text { Points at the box } \\
\text { with a } \\
\text { camera }\end{array}$ & $\begin{array}{l}\text { Music which you will } \\
\text { put in...and this is } \\
\text { something you also } \\
\text { need.. Emil }\end{array}$ \\
\hline
\end{tabular}

\begin{tabular}{|c|c|c|c|}
\hline 5 & Emil & Has his hand raised & The images \\
\hline 6 & Teacher & $\begin{array}{l}\text { Points at the box } \\
\text { with a 'T' }\end{array}$ & $\begin{array}{l}\text { The images and they } \\
\text { should be in iPhoto and } \\
\text { this is? } \\
\text { Patrick? }\end{array}$ \\
\hline 7 & Patrick & Has his hand raised & text \\
\hline 8 & Teacher & & text \\
\hline
\end{tabular}


Each mode of expression in the software (music, image, text) was separately introduced and pointed out in the software (Turns 2, 4, 6).

\section{Introducing the manuscript}

During the first and second lessons the pupils were also instructed to start off by making a manuscript for the film with the aim of figuring out and planning the content before they started to interact with the software, which is illustrated in Excerpt 3. This could be compared to a storyboard but the teacher named it manuscript and the focus was primarily on the linguistic mode, to make a written plan for text and images. In Excerpt 3, the teacher introduced the idea of the manuscript.

\section{Excerpt 3}

\begin{tabular}{|c|c|c|c|c|}
\hline Turn & Actor & Video image & Action/gesture & Speech \\
\hline 1 & Teacher & & $\begin{array}{l}\text { Watching the class } \\
\text { and } \\
\text { showing a sheet of } \\
\text { paper to use } \\
\text { for the manuscript }\end{array}$ & $\begin{array}{l}\text { You have to make a } \\
\text { manuscript first... with } \\
\text { texts and images and } \\
\text { think about that in the } \\
\text { groups... and you must } \\
\text { write on a sheet of paper } \\
\text { before you start working } \\
\text { with the film }\end{array}$ \\
\hline 2 & Teacher & & $\begin{array}{l}\text { Talking to the } \\
\text { class }\end{array}$ & $\begin{array}{l}\text { It is good to have a plan } \\
\text { for the advertising film } \\
\text { otherwise there will be } \\
\text { disagreements in the } \\
\text { groups... and you will } \\
\text { save time this way }\end{array}$ \\
\hline
\end{tabular}

In this event (Excerpt 3 ) the teacher introduced the manuscript primarily through the linguistic mode in combination with the gestural, visual and spatial designs:

- Linguistic design: using elements like the voice and words to introduce the manuscript

- Visual design: showing a piece of paper to use

- Gestural and spatial design: pointing and illustrating in front of the class

According to the observations, the teacher's intention with the design of a manuscript was for the groups to have a plan for their work and to save some time before working with the software (Excerpt 3, Turn 2). This part of the task was designed to be carried out using paper and pen as artefacts. During the third lesson the teacher repeated the software instructions and emphasized the importance of making a manuscript.

\section{Pupils Designing and the Redesign of the Digital Task}

After the introductory mini-lessons, all six groups immediately started working and continued their work during subsequent lessons. During these group processes, the analysis showed that all six groups orchestrated a variety in the multimodal designing afforded by the software, combining still images with words, music, text, and special sound and image effects. They also used 
other software available on the laptop mainly to create photos of their own and when searching for images and facts on the Internet.

As described in Excerpt 1-3, the teacher had introduced the features of image, sound, text in the software, one by one (Excerpt 2) through language, gestures, spatial design, and visual design. The observations of the pupils while they were designing show that all the pupils engaged in activities involving far more features of the software modes than the teacher had instructed them about, and all the groups integrated the meaning-making modes into a multimodal project. They had no difficulty in dragging and dropping images, trying out and inserting different sounds and music, attaching captions, or applying special effects such as closing credits, which is illustrated in Figure 1.
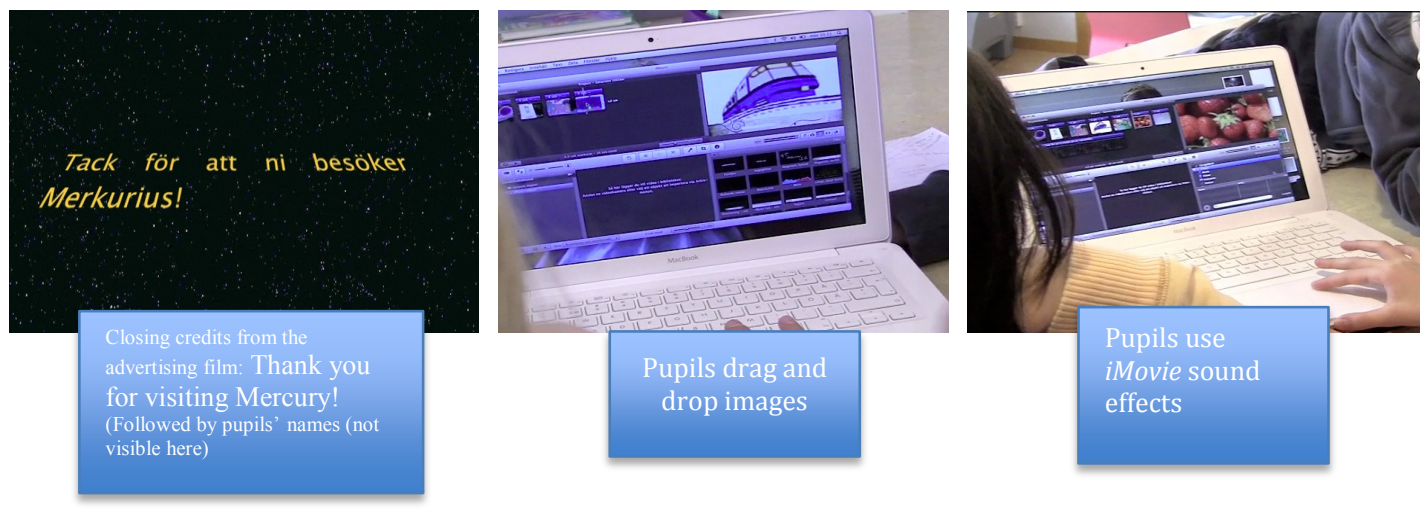

Figure 1: Illustration of pupils' work during the group processes

\section{Working with available designs}

Table 3 provides an overview of the different artefacts, content, and modes that the pupils used during the lessons. The primary modes in use are marked in bold.

Table 3: Features of pupils' meaning-making processes

\begin{tabular}{llll}
\hline Lesson & Artefacts & Content & $\begin{array}{l}\text { Design } \\
\text { modes }\end{array}$ \\
\hline $\mathbf{1}$ & $\begin{array}{l}\text { paper, pen } \\
\text { laptop }\end{array}$ & $\begin{array}{l}\text { Manuscript } \\
\text { Software }\end{array}$ & $\begin{array}{l}\text { Visual, linguistic, but also gestur- } \\
\text { al, spatial, auditory in combina- } \\
\text { tion }\end{array}$ \\
$\mathbf{2}$ & laptop & $\begin{array}{l}\text { Software } \\
\text { Internet } \\
\text { Laptop affordances (e.g., } \\
\text { photo booth) }\end{array}$ & $\begin{array}{l}\text { Visual but also linguistic, gestur- } \\
\text { al, spatial, auditory in combina- } \\
\text { tion }\end{array}$ \\
\hline $\begin{array}{l}\text { Software } \\
\text { lessons }\end{array}$ & laptop & $\begin{array}{l}\text { Laptop affordances (e.g. } \\
\text { photo booth) }\end{array}$ & $\begin{array}{l}\text { Visual but also linguistic, gestur- } \\
\text { al, spatial, auditory in combina- }\end{array}$ \\
\hline
\end{tabular}

During the first lesson all groups started out by making a manuscript for the film. They wrote texts in circles or in boxes on a sheet of paper about the content of different parts of the movie. They wrote what to say in words and ideas for images they could insert. In other words, the lin- 
guistic mode of comments and notes about images was the primary focus of this part of the task. In Figure 2 the manuscript of the Mercury group is given as an example. Altogether they created four different boxes with text in three of them; the fourth box was empty. The manuscript contained facts about the planet, e.g., "Welcome to Mercury the planet that is cold and hot."

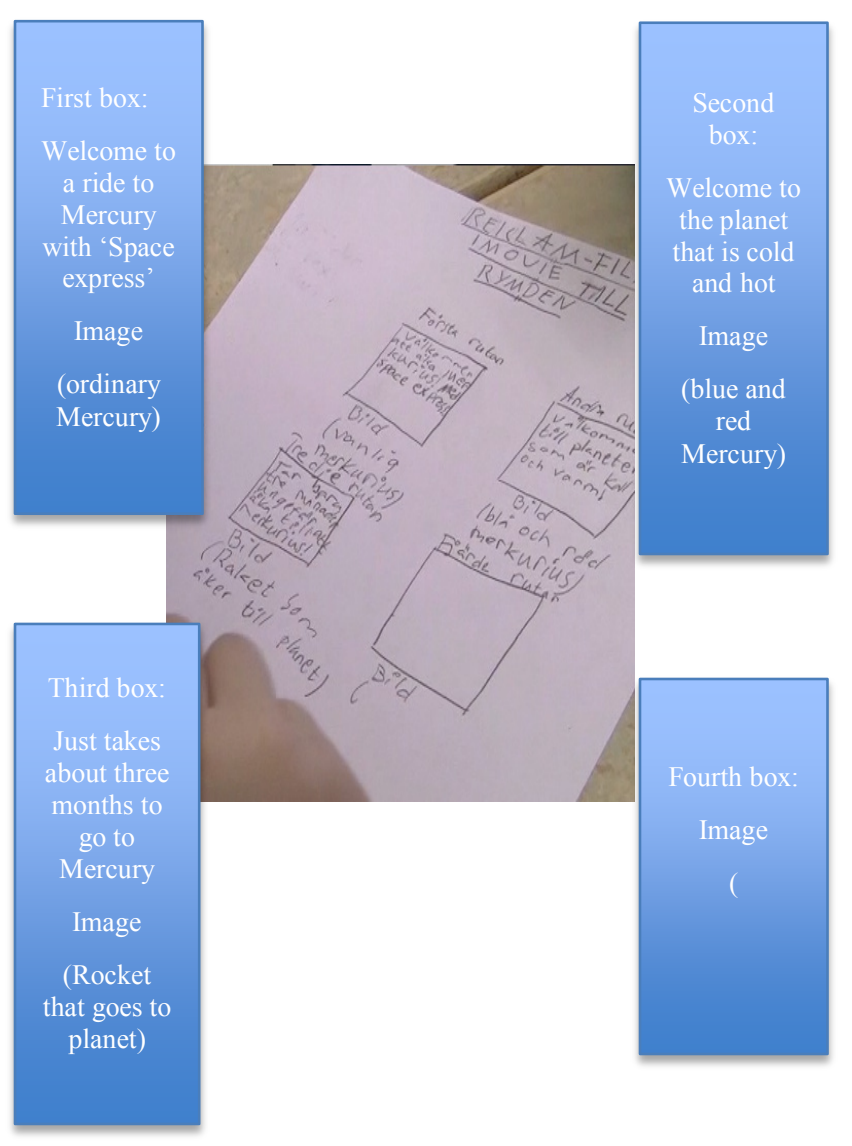

Figure 2: The manuscript of the Mercury group

A text in brackets about finding an image to combine with the text was put under three of the textboxes. The three suggestions for images were 'ordinary Mercury', 'blue and red Mercury,' and 'rocket that goes to planet.' In the fourth textbox there was either a text or an image. After finishing the manuscripts the group started using the software. When they switched over to the laptop they began to work with the first two film clips in accordance with the first two boxes of the manuscript and the text they had written down. At this stage, they did not take into account what was written in the third box. They also ignored the suggestion of images in brackets in the manuscript, and changed the order of images to "an ordinary Mercury" in the second film clip instead of the first. They searched on the Internet to find the image for the second film clip and later on they put in music and sound effects.

When the pupils were creating the third film clip they did not follow the third box of the manuscript (Figure 2). The content of the third box in the manuscript never became a part of the final advertising film. Instead they focused on the suggestion for an image in the second box of the manuscript, "a blue and red Mercury," for which they started searching on the Internet. The images now became the primary focus for the meaning-making process in line with what they wanted to express, as opposed to the manuscript where the images were secondary and put in brackets, and the text was the primary focus. Figure 3 illustrates the first four film clips created by the Mercury group. 


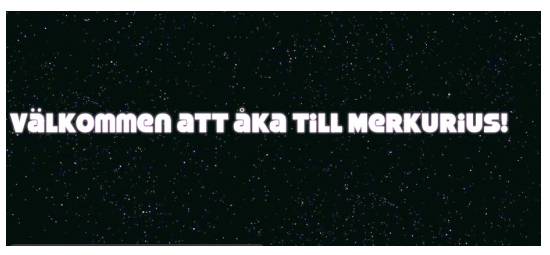

First film clip: Welcome to a ride to Mercury!

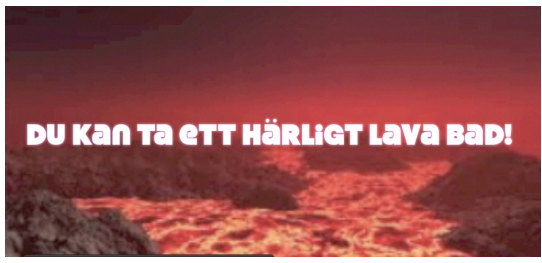

Third film clip: You can have a lovely lava bath

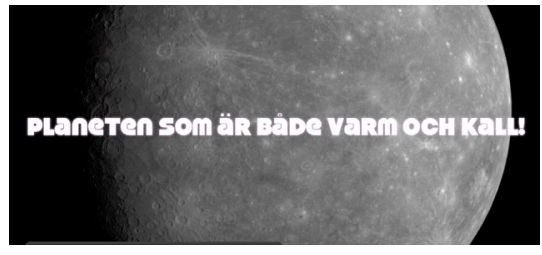

Second film clip: The planet that is both hot and cold

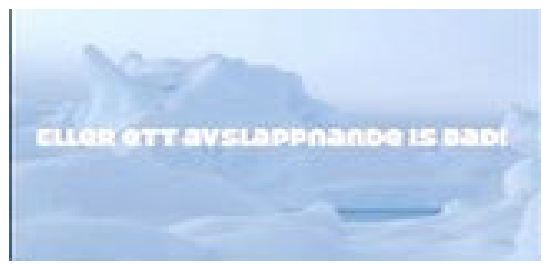

Fourth film clip: or a relaxing ice bath

Figure 3: The first four film clips of the Mercury advertising film

In Excerpt 4, during this event when creating the third clip, the pupils of the Mercury group have further developed their original handwritten manuscript and have now chosen an image of a 'lava bath' to represent the warmth on Mercury and an image of an 'ice bath' to represent the coldness. In this phase of the process the group was primarily focusing on the visual mode in combination with the linguistic mode (the text). They were discussing what to write in combination with the image and they were discussing a text to combine with the image of an 'ice bath'.

\section{Excerpt 4}

\begin{tabular}{|c|c|c|c|c|}
\hline $\begin{array}{l}\text { Tur } \\
\text { n }\end{array}$ & Actor & Video image & Action/gesture & Speech \\
\hline 1 & Pat & & $\begin{array}{l}\text { Starts writing 'ice } \\
\text { bath' }\end{array}$ & $\begin{array}{l}\text { Or an ice bath I think we } \\
\text { write that }\end{array}$ \\
\hline 2 & Martin & & Watching the screen & yeah \\
\hline 3 & Felicia & & $\begin{array}{l}\text { Watching the screen } \\
\text { Pointing at the } \\
\text { screen }\end{array}$ & $\begin{array}{l}\text { A cold ice bath } \\
\text { We have to write some- } \\
\text { thing about the image } \\
\text { of the bath }\end{array}$ \\
\hline 4 & Martin & & Watching the screen & yes \\
\hline 5 & Felicia & & Watching the screen & $\begin{array}{l}\text { Or a nice ice bath? } \\
\text { Or a cooled a cooled... }\end{array}$ \\
\hline
\end{tabular}




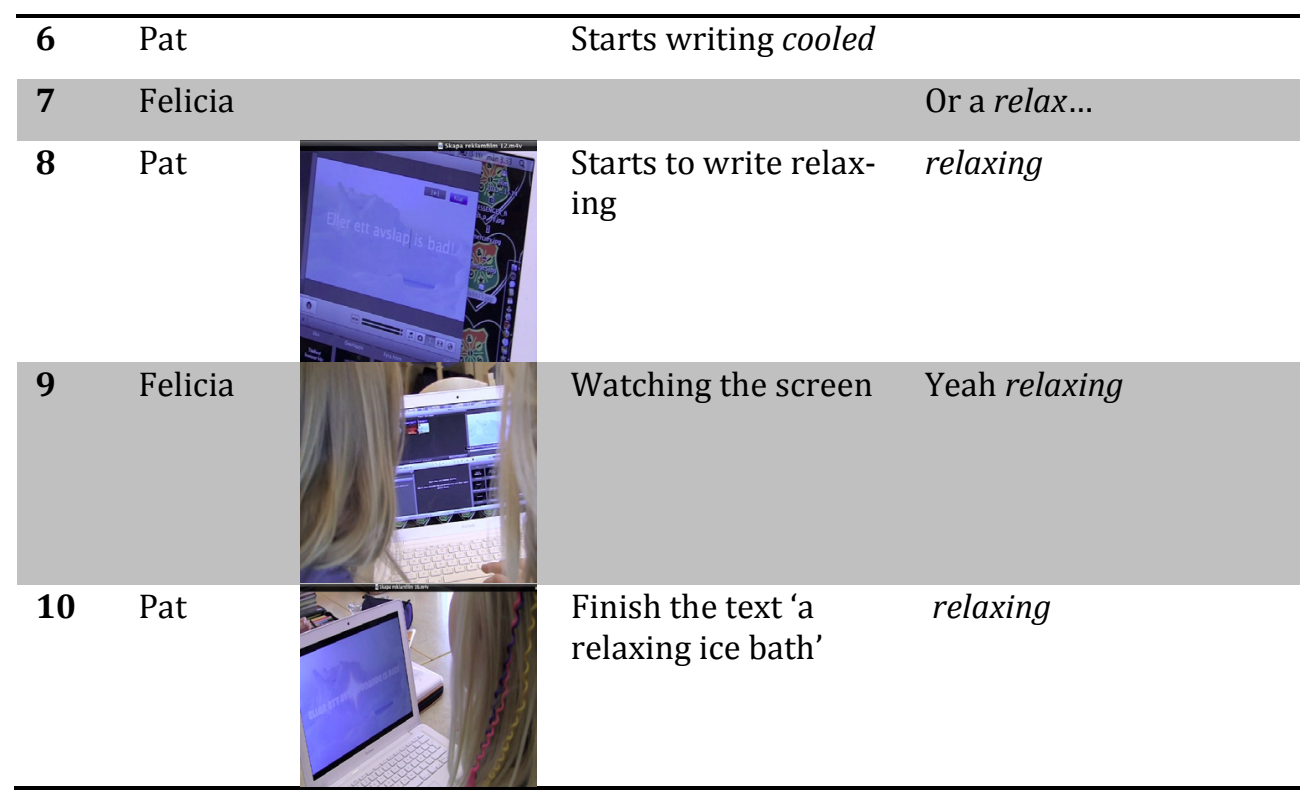

In Excerpt 4, Pat had control over the keyboard and started writing 'ice bath'. Felicia suggested that they had to write something more about the ice bath. She gave some ideas like 'cold', 'nice', 'cooled' (Turns 3-5) and finally the adjective 'relaxing', which she had not finished saying when Pat interrupted (Turn 8). Felicia initiated the idea of adding more adjectives to the text and the other group members, Pat and Martin, supported her ideas and agreed upon using 'relaxing' as an appropriate adjective to combine with the image. In the final product they used 'relaxing ice bath'.

Excerpt 4 is an example of a screen-based activity with the images as a 'central mode' but also the orchestration of various modes into a multimodal product. In the final advertising film the Mercury group chose an image of a lava bath and an ice bath for Clips 3 and 4 (Figure 2) and wrote their message in words and added sound effects from the film-software library. They put the keyword 'space' into the library search box, received two suggestions and chose one of them: 'Space Log'. In their multimodal designing of the advertising film they thus integrated the visual, linguistic and auditory designs.

The image became the central visual point of departure for their multimodal project, which was a common way of designing the resources provided in this film software. The analysis shows that the Mercury group put a lot of effort into combining their images with appropriate texts, trying out suitable adjectives in the communication of their meaning.

The other five groups in this study developed their initial handwritten manuscript in similar ways. Their focus shifted from a mainly linguistic design of the manuscript to engaging in the visual design of images as the primary mode accompanied by text, sound and other visual effects. The film software, the Internet and other photo software on the laptops were in focus.

\section{Discussion}

Examining the teacher's introduction to composing digital advertising films and the pupils' redesign of this task in group work, the case study aimed to analyze the selection of design elements in the teacher's instructions and the pupils' design. First of all, the findings indicate a development in the pupils' work from the linguistic design provided by the teacher towards visual design and images as the central mode of expression in the process of creating advertising films. Further 
findings relate to the task as whole and the lack of subject content resulting from the teacher's primary focus being on introducing the software to the pupils.

With regard to the design elements found in the teacher's instructions and the pupils' group work, the pupils started their design process as the teacher had instructed them and made manuscripts for their films by hand. However, as soon as they started working on the laptops the visual affordances offered in the software and in the laptop were emphasized. As illustrated in Excerpts 1 and 2, the teacher was engaged mainly in linguistic design and talked about using images, text, and sound, which she then visualized through the use of non-digital artefacts, such as a whiteboard or a projector, and through gestures used to point out the different features in the software. The different modes of expression in the software were introduced separately from each other. During the composing process, all six groups orchestrated a multimodal mixture of different modes afforded in the software and combined images with sound, music, text, and special effects, even though in the introductory mini-lessons, the teacher focused on the modes separately. The available designs provided by the digital resources became more important to the pupils than the available designs provided by the teacher. That is, in contrast to the linguistic mode, which was central in the introductory lessons, the images became the central mode of expression in the process of creating advertising films. Even though this was an innovative teacher who aimed to introduce the pupils to the modal affordances of the digital software, the linguistic design dominated in her instruction over other design modes.

The phenomenon of outcomes being different from what the teacher originally intended is nothing new in the school context. However, the findings presented here confirm the linguistic tradition in schools also in the context of introducing digital artefacts for learning. The analysis of design elements shows a development on the part of the pupils from a more traditional printbased school task, engaging the pupils in linguistic composing, towards screen-based activities where the pupils engage in creative and explorative multimodal design. All the groups in the study left the linguistic mode and developed their handwritten manuscripts towards the visual mode as soon as they started working with the software. As demonstrated with the Mercury group, the screen-based activities also encouraged the pupils to collaborate and develop their text further, with more detailed descriptions of the planet in focus. They made use of metaphors and vivid language, which thereby extended the meaning of their multimodal composing. The pupils also orchestrated other digital resources besides the software used in the assignment, created images on their own and searched in web browsers for images on the Internet. The available designs built into the software program became the primary focus in the pupils' work. The pupils also explored the modal affordances during the design process and the redesigned outcome included different modes integrated with each other.

During this task, the semiotic resources of different modes opened up a space for the pupils' communication of meaning and learning. By orchestrating the different modes of images, text, and sound, they designed and redesigned the task into a product with both fact and fiction by communicating about the available designs provided by the software and the Internet. In addition, the communication among pupils during the group work related mainly to the affordances of modes and how to compose the modes to convey the intended meaning. On the other hand, there were no discussions about how to convey their meaning using an advertising film. The teacher had not introduced the significant features of this specific genre; there were no discussions during the introductory mini-lessons concerning the content apart from the question from the pupil about the fantasy element.

The pedagogical implications from the findings of this study highlight above all the adherence to the deeply-rooted tradition of print-based teaching (used here by the teacher despite the digital composing task), the pupils' ability to solve the task in the digital and multimodal redesign, but 
also the absence of reflection about the text genre the pupils were working with and the affordances of different modes to convey their meaning in an advertising film.

The findings also indicate a distinction between how the teacher and the pupils communicate regarding the multimodal modes of expression. The New London Group (2000) argues that: "teachers and students need a language to describe the forms of meaning that are represented in Available Designs and the Redesigned" (p.23). This meta-language should be open-ended, flexible, and not necessarily formalized, and involve talking about images, sound, texts, and meaning making practices. This includes the multimodal relations in digital multimedia (New London Group, 2000). The important thing is to talk about the diversity of genres and the process of producing or selecting images, attaching sound and text to the composition, and integrating these different modes together in a meaningful way. In the data presented here there were no such dialogues observed between the teacher and the pupils, neither during the introductory lessons nor during the designing process during group work. Although the Mercury group did, for instance, discuss how to combine the images and text, a meta-language could be a useful additional tool in the process of integrating different modes, which might help both teachers and pupils to explore and to develop skills in integrating different modes for communication. To develop the classroom communication in the direction of a meta-language requires new forms of communicative competences (Cope\& Kalantzis, 2000). The findings indicate that one of the main issues for teachers is the understanding of the available resources provided by digital technologies in relation to knowledge construction. This understanding has to be made central in teaching practice by developing strategies on how to address multimodal literacy. Further, issues of assessment should then be addressed and we argue for a need to expand the current Swedish curriculum and syllabi with explicit guidelines for assessing technology-mediated multimodal tasks.

\section{Limitations of the Study}

The research in the present paper entails an analysis of a single case with the aim of capturing the contextual premises in a digital classroom setting. The data presented here has been collected with a focus on depth rather than breadth, and the study is oriented towards social practice.

Qualitative case study research has its limitations, such as the external validity (the degree to which the findings can be generalized), and the findings presented here do not make any claims with regard to this. The findings exemplify the classroom orchestration of multimodal resources during a technology-mediated task, strengthening the internal validity by making a good match between the researchers' observations and the theoretical ideas. This is developed through participation in a social group over a long period of time, which allows the researcher to ensure a high level of congruence between concepts and observations (Goetz \& Le Compte, 1984).

However, there are features that have to be taken into account in regard to this study. When dealing with field-notes, one is, of course, working with material that has been filtered through the researcher, which results in an inevitable bias. Also, when people's actions are video recorded the researcher has to decide where to place the camera(s) and when to stop filming, which is a reliability issue (Silverman, 2010).

The methodological ambition of this paper has been to provide as many illustrations as possible from the collected data by visualizing the data through still images and describing gestural, visual, spatial, and auditory modes in order to increase the credibility of the study. However, we are conscious that it is difficult to give a full account of the video recordings and guide the reader through the analysis in order capture the findings that have been selected from the large data collection. 


\section{Conclusions}

This study has analyzed sequences of a learning trajectory and found a distinction in the selection of design elements between the teacher's introductory lessons and how the pupils redesigned the task. This study indicates that there are strong traditions in school and the findings here indicate that the teacher used the linguistic mode in preference to other modes during the instruction lessons. The findings would seem to support our hypothesis about the print-based tradition and its impact on the ways the teacher orchestrates digital resources in the classroom, despite the teacher's previous experience with digital resources in daily teaching. However, the most interesting aspect of the findings relates to the research questions concerning how various modes of expression are orchestrated during a technology-mediated learning task.

As mentioned, the emphasis during the introductory lessons was on the linguistic mode with the use of elements such as voice and words but also the use of non-digital artefacts, even though it was a technology-mediated task. Findings also show how the teacher introduced each mode of expression in the software (music, image, text) separately. Despite the teacher instructions, the pupils transformed the print-based task into a digital multimodal product combining several modes of expression. The pupils thus demonstrated that they have a knowledge of a range of modes for expression that they manage to orchestrate in a meaningful way and that their communication is not limited to the linguistic mode or the traditional medium of paper (Bearne \& Wolstencroft, 2007).

From these findings, a discussion is taking place about the teaching and assessment of modal affordances and multimodal design in digital composing in relation to the outcomes and subject content knowledge. We suggest that, instead of focusing on the technology and software itself, the teacher might develop the means for expression. For instance, the manuscript, which primarily focused on and included the linguistic design, could have been developed into either a digital form or included further modes of expression (images, sound, etc.).

In order to achieve a more coherent classroom communication, a pedagogical suggestion would be to emphasize the development of pupils' communicative skills in relation to the subject content and the digital resources for learning without necessarily teaching practical aspects of using the software. In other words, we suggest that teachers should open up for pupils themselves to become designers by combining the subject content with the interplay of the digital modes e.g. visual, auditory, spatial. This will have a communicative value for both teachers and pupils, creating a common understanding about knowledge construction in technology-mediated tasks, which is also an interesting topic for further research.

Bearne and Wolstencroft (2007) argue that the development of a classroom environment including multimodal resources requires a reviewing of traditional texts for multimodal teaching. It requires teacher knowledge and awareness of multimodal teaching and design, which might introduce the idea of a meta-language (New London Group, 2000). There is also a need for a common discourse about multimodal texts in instruction (e.g., Bearne, 2009; Edward- Groves, 2011).

As in any educational context, the teacher is an important factor in the designing of the classroom task as well as in providing a platform that enables collaborative dialogic learning, where both teachers and pupils contribute to common knowledge building (Warwick et al., 2010). Focusing primarily on technology in linguistic terms might cause difficulties in developing and assessing pupils' multimodal learning and skills. Taking into account that the current Swedish curriculum emphasizes in many places learning goals based on written and spoken language and that there are no explicit tools for assessing multimodal texts (Swedish National Agency for Education, 2011), we argue that there has to be further discussion on this topic in order to develop traditions in schools for including multimodal teaching. 


\section{References}

Baker, W. D., Green, J. L, \& Skukauskaite, A. (2008). In G. Walford (Ed.). How to do educational ethnography. London: the Tufnell Press.

Bearne, E. (2009). Multimodality, literacy and texts: Developing a discourse. Journal of Early Childhood Literacy, 9(2),156-157. London: Sage.

Bearne, E., \& Wolstencroft, H. (2007). Visual approaches to teaching writing: Multimodal literacy 5 - 11. London: Sage.

Bebell, D., \& O'Dwyer, L. M. (2010). Educational outcomes and research from 1:1 computing settings. The Journal of Technology, Learning, and Assessment, 9(1), n1.

Birmingham, P., Davies, C., \& Greiffenhagen, C. (2002). Turn to face the Bard: Making sense of three-way interactions between teacher, pupils and technology in the classroom. Education, Communication \& Information, 2(2-3), 139-161.

Björkwall, A., \& Engblom, C. (2010). Young children's exploration of semiotic resources during unofficial computer activities in the classroom. Journal of Early Childhood Literacy, 10(3), 271-293.

Bryman, A. (2012). Social research methods (4th ed.). Oxford: Oxford University Press.

Cope, B., \& Kalantzis, M. (2000). Multiliteracies: Literacy learning and the design of social futures. South Yarra, Melbourne: Macmillan

Dils, K. (1999). The use of technology to reach the various learning styles of middle school history and social studies students. Journal of the Association for History and Computing, 2(3), November.

Edwards-Groves, C. J. (2011). The multimodal writing process: Changing practices in contemporary classrooms. Language and Education, 25(1), 49-64.

Goetz, J. P., \& Le Compte, M. D. (1984). Ethnography and qualitative design in educational research. Orlando: Academic Press.

Government Offices of Sweden. (2011). ICT for everyone - A digital agenda for Sweden. Ministry of Enterprise Energy and Communications Sweden

Heath, C., Hindmarsh, J., \& Luff, P. (2010). Video in qualitative research: Analysing social interaction in everyday life. Los Angeles: SAGE

Hennessy, R., Deaney, K. R., \& Winterbottom, M. (2007). Pedagogical strategies for using the interactive whiteboard in school science. Learning, Media and Technology, 32(3), 283-301.

Immerfall, S., \& Therborn, G. (Eds.). (2010). Handbook of European societies: Social transformations in the 21st century. New York: Springer.

Jewitt, C. (2006). Technology, literacy and learning: A multimodal approach. London: Routledge.

Jewitt, C. (2008). Multimodality and literacy in school classrooms. Review of Research in Education, $32(1), 241-267$.

Jewitt, C. (2011). Different approaches to multimodality. In C. Jewitt (Ed.) (2011). The Routledge handbook of multimodal analysis (pp. 28-39). London: Routledge.

Kennewell, S., Tanner, H., Beauchamp, G., Parkinson, J., Jones, S., Norman, N., et al. (2007). The use of ICT to improve learning and attainment through interactive teaching. Full research report ESRC end of award report, RES-139-25-0167-A. Swindon: ESRC.

Kress, G. (2005). Gains and losses: New forms of texts, knowledge, and learning. Computers and Composition, 22(1), 5-22.

Kress, G. (2010). Multimodality. A social semiotic approach to contemporary communication. London: Routledge.

Kress, G., \& van Leeuwen, T. (2001). Multimodal discourse: The modes and media of contemporary com- 
munication. London: Arnold.

Mavers, D. (2003). Communicating meanings through image composition, spatial arrangement and links in primary school student mind maps. In C. Jewitt \& G. Kress (Eds.), Multimodal literacy (pp. 19-33). New York: Peter Lang.

Mavers, D., Somekh, B., \& Restorick, J. (2002). Interpreting the externalised images of pupils' conceptions of ICT: Methods for the analysis of concept maps. Computers \& Education, 38(1-3), 187-207.

Merchant, G. (2007). Digital writing in the early years. In J. Coiro, M. Knobel, C. Lankshear, \& D. J. LEU (Eds.), Handbook of research on new literacies (pp. 751-774). New York: Laurence Erlbaum.

Mifsud, L. (2012). Learning with mobile technologies: Perspectives on mediated actions in the classroom. Faculty of Educational Sciences, University of Oslo.

Miller, S. M., \& McVee, M. B. (Eds.). (2012). Multimodal composing in classrooms: Learning and teaching for the digital world. Routledge, Taylor \& Francis Group.

New London Group. (2000). A pedagogy of multiliteracies. Designing social futures. In B. Cope, B. \& M. Kalantzis (Eds.), Multiliteracies: Literacy learning and the design of social futures. South Yarra, Melbourne: Macmillan.

Selander, S., \& Åkerfeldt, A. (2008). Learning and meaning making in the virtual space. In T. Hansson (Ed.), Handbook of research on digital information technologies: Innovations, methods, and ethical issues. Hershey, PA: Information Science Reference.

Silverman, D. (2010). Doing qualitative research: A practical handbook (3rd ed.). London: Sage.

Swedish National Agency for Education. (2011). National curriculum and syllabus. Stockholm: Fritzes.

Swedish National Agency for Education. (2013). It use and it competency in schools report 386. Stockholm: Fritzes.

Tomlinson, M. (2013). Literacy and music in early childhood multimodal learning and design. SAGE Open. Retrieved from http://sgo.sagepub.com/content/3/3/2158244013502498

Vygotsky, L. (1978). Mind in society: The development of higher psychological processes. Cambridge, Mass: Harvard University Press.

Warwick, P., Mercer, N., Kershner, R. \& Kleine Staarman, J. (2010). In the mind and in the technology: The vicarious presence of the teacher in pupil's learning of science in collaborative group activity at the interactive whiteboard. Computer and Education, 55 (2010) 350-362.

Watters, C., Conley, M., \& Alexander, C. (1998). The digital agora: Using technology for learning in the social sciences. Communications of the ACM, 41(1), 50-57. 


\section{Biographies}

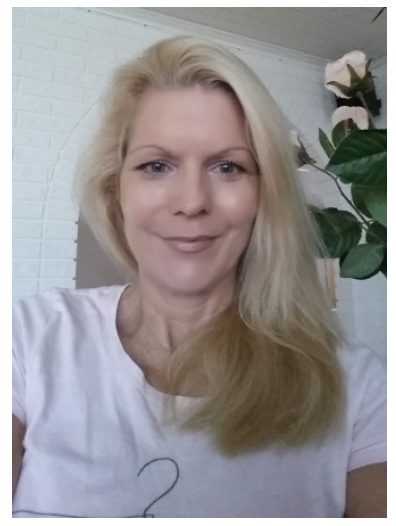

Anne Öman is a doctoral student at the department of Applied IT at the University of Gothenburg, Sweden, within the framework of the centre for education science and teacher research (CUL). Her research concerns the use of digital technologies within primary school education with focus on design, interaction and pupils' multimodal competences. The data observations come from digital classrooms with focus on the creation of products consisting of several modes in combination such as: image, sound, written and spoken language, which challenges what the concept of literacy entails in an educational setting. Anne's recent studies have explored how teachers and pupils' orchestrate digital resources in relation to the subject content and pupils' development of communicative skills. The studies concern technology-mediated instructions in primary school and the analysis of small-group interaction in regard to multimodal meaning-making activities.

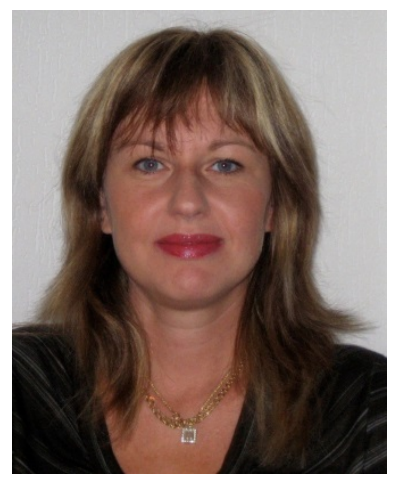

Sylvana Sofkova Hashemi is a $\mathrm{PhD}$ in computational linguistics and associate professor in educational science at University West, Sweden. With focus on digital media and learning, the aim of her research is to advance understanding for the situated accounts of practices, formats, designs and interaction as well as the impact on education in the digital classroom. Based on practice-close approaches, attention is made to analysis and development of technology-mediated teaching in relation to L1 (mother tongue) content and pedagogy, students' development of communicative skills, textual and multimodal competencies and reflective learning. Recent research concerns studies in technology-enriched instruction in early years and analysis of classroom practices in regard to situational choices and interpretation of semiotic resources in digital, multimodal meaningmaking practices. Previous studies concerned development and adaptation of language tools to support reading and writing acquisition and teaching; studies dealing with the use of language aids in text composition by primary school students and developing methods for automatic text revision; students' written communication and language use in school and social media; composing processes in the context of shared spaces online. 